\title{
PENERAPAN MEDIA POP-UP BOOK UNTUK MENINGKATKAN KEAKTIFAN BELAJAR SISWA PADA MATA PELAJARAN IPS KELAS V SDN KEBONSARI KULON I KOTA PROBOLINGGO
}

\author{
Ulfia Lailatul Fadila ${ }^{1}$, Abdul Basit ${ }^{2}$ \\ ${ }^{1}$ Universitas Panca Marga Probolinggo, \\ ulfialailatu102@gmail.com \\ ${ }^{2}$ Universitas Panca Marga Probolinggo \\ abdulbasit@upm.ac.id
}

\begin{abstract}
ABSTRAK
Menggunakan penerapan Media Pop-Up Book untuk Meningkatkan Keaktifan Belajar Siswa Pada Mata Pelajaran IPS Kelas V SDN Kebonsari Kulon I Kota Probolinggo, diperoleh data bahwa banyak siswa yang belum menguasai materi IPS. Mereka merasa bosan dan tidak tertarik untuk mempelajarinya. Alasannya kurang didukung dengan penggunaan media yang maksimal, penguasaan materi guru yang minim. Siswa cenderung pasif dan hanya mendengarkan ceramah dari guru. Dilihat dari permasalahan tersebut, peneliti lebih berfokus pada penggunaan media Pop Up Book yang diterapkan pada siswa kelas V SDN Kebonsari Kulon I agar siswa aktif di dalam kelas saat pembelajaran. Tujuan utama dari penelitian ini adalah menerapkan media Pop Up Book yang mampu meningkatkan keaktifan belajar siswa. Penelitian tersebut menggunakan penelitian kualitatif yang bersifat deskriptif. Jenis penelitian ini adalah penelitian tindakan (action research). Menggunakan teknik pengumpulan data yaitu observasi, wawancara dan dokumentasi. Hasil penelitian tersebut menunjukkan bahwa penerapan media Pop Up Book dapat meningkatkan keaktifan belajar siswa pada pembelajaran IPS kelas V di SDN Kebonsari Kulon 1 Kota Probolinggo. Terlihat peningkatan dari pra siklus sampai siklus II, 24 siswa yang dapat mencapai kriteria keaktifan belajar dengan baik. Dari data tersebut dapat dihitung bahwa $80 \%$ jumlah siswa yang hadir mampu memenuhi kriteria ketuntasan dengan seluruh siswa sudah aktif dalam kegiatan pembelajaran. Sementara kriteria keberhasilan penelitian ini adalah $75 \%$ jumlah siswa. Guru mampu membuat siswa aktif di dalam kelas.
\end{abstract}

Kata kunci: Penerapan, Media Pop Up Book, Keaktifan Belajar Siswa

\begin{abstract}
Implementation Of Buku Pop-Up Media To Improve Student Learning Activity In Class V Social Studies Subjects At SDN Kebonsari Kulon I, Probolinggo City, get the data if so many students have yet to master social studies material. They're bored and not interested in learning. The reason is less supported by maximum media use, scant teacher material mastery. Students tend to be passive and listen only to talks from teachers. In view of the problem, researchers focus more on the use Pop Up Book media that is applied to class V SDN Kebonsari Kulon 1 to keep students active in class while learning. The primary purpose of this study is to implement a Pop Up Book media capable of increasing the activity of students study. It used descriptive qualitative research. This kind of research is action research. Using data collection techniques to observe, interview and document. The study found that application of Pop Up Book media can increase the activity of students studies in IPS class V in SDN Kebonsari Kulon 1 Probolinggo City. Seen an increase from cycle, 24 students who could achieve the activitation criteria are learning well. From the data it could be calculated that $80 \%$ of the students in attendance were able to meet the staging criteria with all students already active in the learning activities. While the success criteria of this study are $75 \%$ of the students. Teacher can make students active in the classroom.
\end{abstract}

Keywords: Application, Pop Up Book Media, Activity Students.

Copyright (c) 2020 Abdul Basit, Ulfia Lailatul Fadila 


\section{PENDAHULUAN}

Belajar merupakan cara membentuk dan mengarahkan kepribadian manusia. Belajar akan terjadi dengan baik apabila ada timbal balik yang memengaruhi peserta didik tersebut dari segi perilaku. Belajar membuat seseorang tersebut mengalami perubahan tingkah laku karena pengalamannya sendiri terjadi secara berulang-ulang di dalam suatu situasi. Perubahan itu menjadi tolak ukur untuk peningkatan kualitas dan kuantitas seseorang ${ }^{1}$. Oleh karena itu, belajar adalah suatu kegiatan yang penting dialami oleh siswa agar terjadi perubahan dari tingkah laku dan pengetahuannya bertambah seiring proses yang dilakukan dalam belajar.

Pembelajaran secara bahasa adalah terjemahan dari kata instruction (Inggris) $^{2}$. Seperti yang kita ketahui, jika proses pembelajaran saat ini diharuskan untuk berorientasi kepada kepentingan belajar siswa (student centered). Pembelajaran merupakan bentuk kegiatan yang melibatkan seseorang karena ingin mendapatkan pengetahuan, keterampilan dan nilai-nilai positif dengan memanfaatkan berbagai sumber untuk belajar. Terjadinya pembelajaran karena ada siswa sebagai pembelajar dan guru sebagai fasilitator ${ }^{3}$. Komunikasi antara guru dan siswa dapat diartikan sebagai penyaluran pesan. Guru harus mampu memberikan motivasi terhadap cara belajar sehingga siswa mampu menguasai bahan ajar dan sukses dalam belajar. Guru dalam hal ini hendaknya berperan lebih aktif dalam mengelola kelas dan mampu memberi motivasi pada siswa agar mau belajar dan dapat menguasai materi yang diajarkan serta berhasil dalam belajar.

Guru harus mampu menjadi idola dan dapat menjadi motivasi bagi siswanya, apapun pelajaran yang akan diberikan. Untuk mengembangkan kemampuan tersebut, diperlukan alat bantu pembelajaran yaitu media belajar yang tepat dan efektif sehingga terciptakan suasana belajar yang kondusif dan mendorong keberhasilan proses belajar mengajar. Komponen-komponen pembelajaran yang saling berkaitan diantaranya harus ada tujuan, materi, metode, media dan evaluasi.

Kedudukan media disini sebagai alat bantu belajar mengajar. Dengan adanya media ini dapat mempertinggi proses belajar siswa dalam pengajaran yang pada gilirannya diharapkan dapat mempertinggi hasil belajar siswa yang ingin dicapai. Menurut Susanto media belajar merupakan salah satu faktor yang dapat meningkatkan pemahaman siswa. Saat menggunakan media belajar, siswa akan senang dan mudah memahami materi yang diberikan. Dari penggunaan media tersebut harus ada komunikasi guru dengan siswa dan siswa dengan siswa yang lain. Selain itu, adanya interaksi yang baik saat proses belajar mengajar antara guru dengan siswa dan di antara siswa dan siswa yang lainnya. Oleh karena itu, penggunaan media belajar perlu diperhatikan saat proses belajar berlangsung.

Media pembelajaran adalah perantara dalam membantu guru untuk kemudahan, kelancaran serta keberhasilan proses belajar sebagaimana yang

\footnotetext{
${ }^{1}$ Ahmad Sutanto. Pengembangan Pembelajaran IPS di Sekolah Dasar (Jakarta: Prenadamedia Group, 2014). 1

${ }^{2}$ Deni Kurniawan. Pembelajaran Terpadu: Teori, Praktik dan Penilaian (Bandung: Pustaka Cendikia Utama, 2011).

${ }^{3}$ Susilana \& Riyana, Media Pembelajaran (Bandung: Wacana Prima, 2009)
} 
Penerapan Media Pop-Up Book Untuk Meningkatkan Keaktifan Belajar Siswa pada Mata Pelajaran IPS Kelas V SDN Kebonsari Kulon I Kota Probolinggo

diharapkan. Media visual adalah jenis media yang paling mudah untuk digunakan serta dalam pengaplikasiannya juga tidak rumit. Karena sejatinya media visual menunjukkan wujud yang konkret sehingga mendukung proses belajar siswa. Melalui penggunaan gambar/foto yang realistis lebih menunjukkan pokok masalah dibandingkan dengan media verbal semata ${ }^{4}$. Pada penelitian kali ini mengembangkan media pembelajaran menggunakan media Pop Up Book. Media yang menarik untuk siswa khususnya kelas V sekolah dasar karena membuat buku yang dimiliki tidak monoton hanya tulisan saja. Media Pop Up Book suatu perpaduan antara unsur dua dimensi dan tiga dimensi yang unik. Sekilas hampir sama dengan origami, dimana kedua seni ini mempergunakan teknik melipat kertas.

Pop Up lebih cenderung pada pembuatan mekanis kertas yang dapat membuat gambar tampak lebih berbeda dari sisi perspektifnya atau sudut pandangnya ${ }^{5}$. Hal ini akan membuat siswa tertarik untuk belajar khususnya untuk belajar IPS tentang kondisi geografis di Indonesia. Media Pembelajaran Pop Up Book merupakan sebuah buku yang dikembangkan bersifat tiga dimensi berupa lipatan-lipatan kertas yang ketika di buka akan menimbulkan kesan timbul yang menarik $^{6}$. Media pembelajaran yang menarik secara visual diharapkan akan lebih memicu rasa ingin tahu dan meningkatkan pengetahuan bagi siswa kelas V SDN Kebonsari Kulon II Kota Probolinggo.

Ilmu Pengetahuan Sosial (IPS) merupakan gabungan dari ilmu-ilmu sosial dan humaniora, diantaranya yaitu sosiologi, sejarah, geografi, ekonomi, politik, hukum dan budaya. Pembelajaran IPS di SD lebih mengarahkan pada peran peserta didik sebagai makhluk sosial sehingga menjadi warga negara yang baik. Tujuan pembelajaran IPS adalah mampu membantu setiap individu khususnya siswa sekolah dasar untuk meningkatkan aspek ilmu pengetahuan, keterampilan dan nilai-nilai keterampilan ${ }^{7}$. Sementara itu masih banyak siswa yang malas untuk membaca, belajar dan mengerjakan soal-soal latihan secara mandiri, termasuk mengupas dan menyajikan pembelajaran IPS menjadi mata pelajaran yang kurang menarik bagi siswa.

Selain itu, mata pelajaran IPS khususnya materi pokok kondisi geografis di Indonesia merupakan mata pelajaran yang kurang menarik bagi siswa. Hal ini terjadi karena mata pelajaran membahas peta Kepulauan Indonesia yang luas dari Sabang sampai Merauke dengan berbagai suku bangsa, budaya sehingga siswa kurang mengetahui keragaman tersebut. Berbagai metode dan media pembelajaran yang menyarankan serta telah diterapkan guru di kelas ${ }^{8}$. Terutama media untuk mempelajari Kepulauan Indonesia hanya berdasarkan peta yang monoton. Untuk menyempurnakan media yang ada sebelumnya peneliti menggabungkan antara

\footnotetext{
${ }^{4}$ Sadiman \& dkk. Media Pendidikan. (Jakarta: PT. Raja Grasindo Persada. 2011)

${ }^{5}$ Eli Sri Mulianti. Pengembangan Media Pembelajaran Pop Up Book Pembelajaran Matematika Kelas II (Tesis. 2017). 4

${ }^{6}$ Diah Rahmawati. Pengembangan Media Pembelajaran Pop Up Book untuk Siswa SDLB Tunarungu Kelas IV (Skripsi. 2017). 3

${ }^{7}$ Ahmad Sutanto. Pengembangan Pembelajaran IPS di Sekolah Dasar (Jakarta: Prenadamedia Group, 2014). 6

${ }^{8}$ Sarifah Nurhasanah. Penerapan Model Pembelajaran Kooperatif Tipe STAD Untuk Meningkatkan Pemahaman Peristiwa Proklamasi Indonesia dalam Pembelajaran IPS pada Siswa Kelas V (Skripsi. 2010). 3
} 
tulisan yang bersifat dua dimensi dengan seni melipat kertas agar menjadi tiga dimensi menjadi Pop Up Book.

Menurut Sardiman keaktifan adalah kegiatan yang bersifat fisik ataupun mental, entah itu berbuat dan berpikir sebagai suatu rangkaian yang tidak dapat dipisahkan. Belajar yang berhasil dapat melalui berbagai macam aktivitas, baik aktivitas fisik maupun psikis. Aktivitas fisik tersebut dapat berupa kegiatan aktif menggerakkan anggota badan, membuat sesuatu, bermain ataupun bekerja. Bukan hanya sekedar duduk dan mendengarkan, melihat atau hanya pasif saja. Siswa yang memiliki aktivitas psikis (kejiwaan) adalah jika daya jiwanya bekerja sebanyak-banyaknya atau keseluruhan berfungsi dalam rangka pembelajaran.

Keaktifan belajar siswa merupakan unsur dasar yang penting bagi keberhasilan proses pembelajaran. Karena dalam suatu proses pembelajaran itu akan mengembangkan kreativitas siswa dengan berbagai interaksi dan pengalaman belajar ${ }^{9}$. Proses pemikiran siswa tersebut yang akan membuat siswa aktif di dalam kelas. Mereka akan aktif membangun pemahaman atas persoalan atau masalah yang mereka hadapi dalam proses pembelajaran. Sehingga penyampaian oleh guru menjadi lebih bermakna dan lebih dipahami oleh siswa.

Kebanyakan pembelajaran IPS yang dilakukan didalam kelas menggunakan model pembelajaran yang masih bersifat konvensional, belum ada improvisasi dalam pembelajaran. Tidak mengikuti perkembangan zaman sekarang menggunakan model kontekstual (contextual teaching and learning). Sehingga pembelajaran yang diajarkan ke siswa terkesan bosan dan monoton. Media yang digunakan pun tidak up to date (terbaru) membuat siswa tidak mudah menghafal materi pelajaran IPS khususnya materi Kepulauan Indonesia. Siswa hanya dituntut untuk membaca sendiri bukunya tentang materi letak Indonesia di peta yang menyebabkan kadangkala siswa tidak mau dan malas membaca.

Pada kenyataan di lapangan yang didapat dari penjelasan guru kelas V SDN Kebonsari Kulon I, guru menjelaskan materi yang ada di buku dengan menggunakan metode ceramah. Guru menjelaskan Kepulauan Indonesia melalui peta dengan menggunakan gaya bahasanya sendiri lalu siswa diberikan tugas untuk membuat peta. Sehingga siswa sulit mempelajari IPS materi Kepulauan Indonesia. Karena setiap siswa mempunyai konsentrasi yang berbeda-beda. Selain itu, materi yang diajarkan sangat banyak dengan berbagai hafalan yang susah. Siswa merasa bosan dan tidak tertarik dengan materi tersebut. Banyak siswa yang tidak memahami materi Kepulauan Indonesia yang diterangkan oleh guru. Mereka kesulitan menghafal nama pulau, suku bangsa, jumlah pulau, letak Indonesia dan pengaruh Kepulauan Indonesia terhadap ekonomi, budaya, sosial, komunikasi dan transportasi.

Dari permasalahan di atas peneliti dapat memberikan solusi alternatif untuk mengatasi masalah yang terjadi di Kebonsari Kulon I. Solusi alternatif tersebut diantaranya adalah menggunakan model kooperatif dalam menyampaikan materi Kepulauan Indonesia. Solusi yang lainnya adalah menggunakan media yang menarik yakni media Pop-Up Book dengan metode drill yang dapat dilakukan dengan berulang-ulang sampai keaktifan belajar siswa dalam menjawab pertanyaan dapat terlihat. Selain itu, siswa harus terlihat aktif ketika mencari

${ }^{9}$ Sinar. Metode Active Learning: Upaya Peningkatan Keaktifan dan Hasil Belajar Siswa (Sleman: DeePublish, 2018). 9 
informasi di dalam media tersebut. Siswa mampu mengerjakan lembar kegiatan siswa yang telah dibuat guru secara berkelompok. Penggunaan model kooperatif ini salah satu dari model pembelajaran namun akan kurang jika tidak didukung dengan media. Media Pop Up Book digunakan ketika proses pembelajaran berkelompok. Di dalam media tersebut berisi materi tentang Kepulauan Indonesia. Antara lain karakteristik 5 pulau di Indonesia, kebudayaan yang ada di Indonesia dan jalur pelayaran. Sehingga pembelajarannya berdasarkan pembentukan kelompok-kelompok untuk siswa amati yang dikaitkan dengan fenomenafenomena sosial ${ }^{10}$.

Sedangkan dengan menggunakan media Pop Up Book dalam pembelajaran IPS membuat ilustrasi materi Kepulauan Indonesia terlihat lebih menarik dan jelas dengan gambar tiga dimensi dan beraneka warna. Terdapat kejutan-kejutan dalam setiap halaman yang akan dibuka. Membantu anak dapat memahami dan mengerti materi pelajaran yang disampaikan oleh guru pada setiap pertemuan sehingga diharapkan mampu membangkitkan keaktifan belajar siswa. Meski mahal dan rumit dalam proses pembuatannya, tetapi didesain sedemikian rupa agar dapat dipakai oleh siswa.

Dari berbagai solusi alternatif yang diberikan, peneliti lebih memilih menggunakan media yang menarik yakni media Pop-Up Book dengan metode drill yang dapat dilakukan dengan berulang-ulang sampai keaktifan belajar siswa dalam menjawab pertanyaan dapat terlihat. Karena media Pop Up Book mampu menarik minat siswa untuk belajar IPS yang terkesan menghafal. Mereka tidak pusing lagi untuk menjawab soal yang diberikan guru karena alat yang mendukung belajarnya sangat variatif dan berbeda dari media pembelajaran yang lain. Selain itu, media Pop Up Book memberikan kreativitas pada siswa saat menggunakannya. Berbantuan metode drill (berulang-ulang) sehingga siswa lebih memahami materi yang diajarkan dan mampu meningkatkan keaktifan belajar siswa pada mata pelajaran IPS.

\section{METODE PENELITIAN}

Penelitian kali ini menggunakan penelitian kualitatif yang bersifat deskriptif. Penelitian kualitatif merupakan metode penelitian yang sifatnya filsafat postpositivisme yang digunakan untuk meneliti kondisi objek secara alamiah ${ }^{11}$. Sifat alamiahnya, yaitu penelitian ini berkaitan erat dengan keberlangsungannya proses pembelajaran. Jenis penelitian ini adalah penelitian tindakan (action research). Penelitian ini merupakan bentuk integrasi yang bersifat refleksi partisipatif, kolaboratif, dan spiral yang memiliki tujuan untuk melakukan perbaikan sistem, metode, kerja, proses, isi, kompetensi, dan situasi ${ }^{12}$. Action Research dilaksanakan dalam proses sistematis yang terdiri dari empat tahapan yaitu membangun dan menganalisa masalah (Constructing), merencanakan

\footnotetext{
${ }^{10}$ Eny Ike Suharyati. Penerapan Model Pembelajaran Kooperatif dalam Meningkatkan Kemampuan Siswa Mendeskripsikan Kondisi Fisik Wilayah dan Penduduk Indonesia (Widya Wacana Vol 11 No 1: Skripsi. 2016). 2

${ }^{11}$ Sugiyono. Metode Penelitian Pendidikan Pendekatan Kuantitatif, Kualitatif, dan R\&D (Bandung: Alfabeta. 2010)

${ }^{12}$ Suharsimi Arikunto, Suhardjono dan Supardi. Penelitian Tindakan Kelas (Jakarta: Bumi Aksara. 2010)
} 
tindakan (Playing Action), melaksanakan tindakan (Taking Action), dan mengevaluasi tindakan (Evaluating Action).

Peneliti sebagai instrumen utama sekaligus pengumpul data, sekaligus sebagai observer partisipan. Lokasi penelitian ini adalah di SDN Kebonsari Kulon I Kota Probolinggo. Sumber data yang diperoleh dari siswa SDN Kebonsari Kulon I, guru, pihak lain yang berhubungan, serta sumber data seperti arsip atau dokumentasi, lembar observasi, lembar pertanyaan, hasil wawancara. Teknik pengumpulan data menggunakan observasi, wawancara dan dokumentasi. Dalam Action Research ada beberapa faktor yang harus dilalui untuk menganalisis data yang telah di dapat yaitu faktor kontekstual, kualitas hubungan, kualitas proses Action Research, dan keluaran dari Action Research.

\section{HASIL DAN PEMBAHASAN}

Berdasarkan hasil observasi terhadap kegiatan pembelajaran IPS semester ganjil tahun 2018-2019 pada materi kondisi geografis di Indonesia yang dilakukan pada siswa kelas V dan guru SDN Kebonsari Kulon 1 Kota Probolinggo, guru dalam kegiatan pembelajarannya masih menggunakan pembelajaran yang konvensional, kegiatan pembelajaran cenderung berpusat pada guru. Guru dalam menyampaikan materi kepada siswa masih menggunakan metode ceramah dan penugasan, sehingga siswa hanya berperan sebagai pendengar yang pasif dan kurang memperhatikan ketika pembahasan soal di papan tulis.

Adapun hasil pre test awal siswa pada materi kondisi geografis di Indonesia terdapat 1 siswa yang tidak memenuhi kriteria penilaian keaktifan belajar di kelas sebelum menggunakan Pop Up Book. Diperoleh data hasil keaktifan belajar siswa sebelum dilakukannya tindakan adalah sebagai berikut.

Tabel 4.1 Hasil Pratindakan (sebelum ada media Pop Up Book)

\begin{tabular}{|l|l|l|l|}
\hline \multicolumn{1}{|c|}{ Jumlah Siswa } & \multicolumn{3}{c|}{30 Siswa } \\
\hline Siswa aktif & 5 Siswa & Siswa aktif & 5 Siswa \\
\hline Siswa kurang aktif & 23Siswa & Siswa kurang aktif & 23Siswa \\
\hline Siswa tidak aktif & 1 Siswa & Siswa tidak aktif & 1 Siswa \\
\hline
\end{tabular}

Berdasarkan data pada tabel 4.1 dijelaskan bahwa hasil pratindakan untuk mengukur keaktifan belajar siswa masih kurang.Dari 29 siswa terdapat 5 siswa aktif saat melakukan pre test. Lima siswa tersebut selalu bertanya jika mereka tidak memahami soal yang diberikan. Saat berdiskusi dengan teman sebangku saling membantu untuk mencari jawaban lewat buku dan pengetahuan yang dimiliki, menjawab pertanyaan dengan tepat dari guru, mengemukakan pendapat dengan baik. Sedangkan 24 siswa yang lainnya masih kurang aktif untuk bertanya dan untuk berdiskusi hanya salah satu teman saja yang mengerjakan. Kadangkala mereka mencontoh jawaban teman yang telah selesai mengerjakan. Terdapat 1 siswa yang sama sekali tidak aktif untuk mengikuti pelajaran. Guru harus mendekati terlebih dahulu dan membimbing untuk mengerjakan tugas secara individu maupun kelompok. 
Berdasarkan hasil observasi pada pratindakan dapat disimpulkan bahwa keaktifan belajar siswa masih tergolong rendah karena lebih banyak siswa yang terlihat kurang aktif dalam proses pembelajaran, hal ini dapat disebabkan karena proses pembelajaran yang masih berpusat pada guru, guru cenderung menjelaskan dan dilanjut pemberian tugas. Peneliti melakukan penelitian selama 2 siklus tiaptiap siklus terdiri dari 2 kali pertemuan. Pengamatan pada hasil belajar pada siklus 1 yang terdiri dari pertemuan pertama dan kedua dapat dilihat pada tabel sebagai berikut.

Tabel 4.2 Hasil Observasi Keaktifan Belajar Siklus I

\begin{tabular}{|l|l|l|l|}
\hline \multicolumn{1}{|c|}{ Jumlah siswa } & \multicolumn{3}{|c|}{30 Siswa } \\
\hline Siswa aktif & 16 Siswa & Siswa aktif & $\begin{array}{l}16 \\
\text { Siswa }\end{array}$ \\
\hline Siswa kurang aktif & 13 Siswa & Siswa kurang aktif & $\begin{array}{l}13 \\
\text { Siswa }\end{array}$ \\
\hline Siswa tidak Aktif & 0 Siswa & Siswa tidak Aktif & 0 Siswa \\
\hline
\end{tabular}

Dari data tabel 4.2 tersebut dapat diketahui bahwa terdapat 16 siswa $(52,8$ $\%$ ) mengalami keaktifan belajar dan 13 siswa (42,9\%) yang lainnya masih belum terlihat keaktifan belajarnya. Adapun dari keseluruhan data ada 4 siswa yang aktif di dalam kelas dengan memenuhi keseluruhan aspek penilaian. Berdasarkan hasil observasi dan analisis data yang dilakukan pada siklus I guru sudah melaksanakan pembelajaran dengan menggunakan media Pop Up Book siswa terlihat sangat antusias dan bersemangat, akan tetapi ada beberapa siswa tidak mau tertarikuntuk mempelajari materi pada Pop Up Book, ada beberapa siswa yang masih tidak aktifmenanyakan materi yang tidak diketahui, ada yang tidak ikut saat kegiatan diskusi. Pada saat maju untuk menyajikan hasilnya, siswa juga masih merasa malu-malu dan saling menunjuk antar anggota tiap kelompoknya ketika disuruh memaparkan jawabannya, keaktifan belajar siswa sudah mengalami peningkatan dari hasil pratindakan ke tindakan siklus I, meskipun belum mencapai kriteria ketuntasanyang ingin dicapai.

Untuk meningkatkan keaktifan belajar siswa peneliti memberikan pengarahan, penguatan dan pemahaman lebih kepada siswapada waktu penggunaan media Pop Up Book untuk membantu dalam pembelajaran. Siswa dapat mencari informasi dari kegiatan yang diberikan dari media Pop Up Book ini. Sehingga nantinya siswa bisa mampu aktif bertanya, berdiskusi, dan mengisi di LKS dengan tepat dan mandiri. Karena masih belum memenuhi target, maka peneliti melanjutkan pada siklus 2. Pengamatan pada hasil belajar pada siklus II yang terdiri dari pertemuan pertama dan kedua dapat dilihat pada tabel sebagai berikut.

Tabel 4.4 Hasil Observasi Keaktifan Belajar Siklus II

\begin{tabular}{|l|l|l|l|}
\hline \multicolumn{1}{|c|}{ Jumlah siswa } & \multicolumn{3}{c|}{ 30 Siswa } \\
\hline Siswa aktif & 16 Siswa & Siswa aktif & $\begin{array}{l}16 \\
\text { Siswa }\end{array}$ \\
\hline Siswa kurang aktif & 13 Siswa & Siswa kurang aktif & 13 \\
\hline
\end{tabular}


Penerapan Media Pop-Up Book Untuk Meningkatkan Keaktifan Belajar Siswa pada Mata Pelajaran IPS Kelas V SDN Kebonsari Kulon I Kota Probolinggo

\begin{tabular}{|l|l|l|l|}
\hline & & & Siswa \\
\hline Siswa tidak Aktif & 0 Siswa & Siswa tidak Aktif & 0 Siswa \\
\hline
\end{tabular}

Dari data tabel 4.4 tersebut dapat diketahui bahwa terdapat 24 siswa ( 80 $\%)$ mengalami keaktifan belajar dan 6 siswa (20\%) yang lainnya masih belum terlihat keaktifan belajarnya. Pada siklus II guru sudah melaksanakan pembelajaran dengan menggunakan media Pop Up Book siswa terlihat sangat antusias dan bersemangat, beberapa siswa tertarik untuk mempelajari materi pada Pop Up Book, ada juga beberapa siswa yang aktif menanyakan materi yang tidak diketahui dan media Pop Up Book sangat membantu siswa. Ada yang ikut saat kegiatan diskusi dengan baik.Pada saat maju untuk menyajikan hasilnya, siswa juga sudah berani dan tepat dalam menjawab pertanyaan yang diberikan.

Sebelum pembelajaran siklus 1, guru melakukan pretest pada siswa tanpa menggunakan media Pop Up Book terlebih dahulu. Terlihat bahwa siswa masih kesulitan dalam menjawab soal. Hanya 5 siswa yang menjawab pertanyaan dengan baik. Kelima siswa tersebut sering mengajukan pertanyaan dan mengerjakan tugas yang diberikan dengan baik. Hal ini ditunjukkan selama di kelas mereka bekerja sama dengan teman sebangku dalam menjawab soal. Saat guru menyuruh untuk menyajikan hasil diskusi, 5 siswa tersebut secara bergantian menyampaikan hasilnya. Sementara 24 siswa lainnya masih tidak nampak antusias untuk belajar IPS. Terlihat jelas memang banyak yang belum memahami kondisi geografis yang ada di Indonesia.

Mereka merasa bingung dan tidak tahu tentang materi tersebut. Saat guru menunjukkan Pop Up Book keseluruhan siswa masih belum banyak yang mengenal. Mereka seakan baru melihat buku dengan desain seperti itu. Oleh karena itu, pada pertemuan selanjutnya guru mengenalkan Pop Up Book kepada siswa untuk belajar IPS di kelas. Pada siklus ke 2, siswa mulai tenang dalam berdiskusi dan saling bekerja sama untuk menjawab pertanyaan yang diberikan. Menuliskan jawaban pada LKS secara mandiri, tidak lagi mencontek jawaban teman.

Mereka juga semakin antusias untuk membuka media Pop Up Book setiap kali ada materi yang tidak mereka ketahui. Guru hanya mengawasi dan membantu jika terdapat materi yang belum jelas untuk lebih diterangkan kembali. Siswa juga terlihat mulai berani menuliskan hasil diskusi dengan temannya di depan kelas. Mereka juga menyenangi pelajaran IPS tentang materi kondisi geografis di Indonesia. Dibandingkan dengan awal pre test dan siklus 1 mereka masih menganggap pelajaran IPS itu tidak menyenangkan.

\section{PENUTUP}

Berdasarkan hasil penelitian tersebut, penerapan media Pop Up Book dapat meningkat keaktifan belajar siswa pada pembelajaran IPS kelas V di SDN Kebonsari Kulon 1 Kota Probolinggo. Hal tersebut dilihat pada hasil penelitian, berdasarkan pra siklus yang telah dilakukan menunjukan bahwa hanya 16,6 \% dari total jumlah siswa yang mampu memenuhi kriteria keaktiafan belajar siswa, dimana 5 siswa dari 30 siswa aktif dalam kegiatan pembelajara. Sementara 23 dari 30 siswa masih kurang aktif dalam belajar di kelas. lalu pada siklus I jumlah 
Penerapan Media Pop-Up Book Untuk Meningkatkan Keaktifan Belajar Siswa pada Mata Pelajaran IPS Kelas V SDN Kebonsari Kulon I Kota Probolinggo

siswa yang memenuhi kriteria meningkat 36,2 \% menjadi 52,8 \% dimana 13 dari 30 siswa belum mencapai kriteria keberhasilan. Kemudian pada siklus II , 24 dan 30 siswa yang hadir dapat mencapai kriteria keaktifan belajar dengan baik. Dari data tersebut dapat dihitung bahwa $80 \%$ jumlah siswa yang hadir mampu memenuhi kriteria ketuntasan dengan seluruh siswa sudah aktif dalam kegiatan pembelajaran. Sementara kriteria keberhasilan penelitian ini adalah $75 \%$ jumlah siswa. Guru mampu membuat siswa aktif di dalam kelas dan merubah kebiasaan belajar siswa menjadi lebih baik.

\section{DAFTAR PUSTAKA}

Arikunto, S., Suhardjono, \& Supardi. (2010). Penelitian Tindakan Kelas. Jakarta: Bumi Aksara.

Kurniawan, D. (2011). Pembelajaran Terpadu: Teori, Praktik dan Penilaian. Bandung: Pustaka Cendikia Utama.

Mulianti, E. S. (2017). Pengembangan Media Pembelajaran Pop-Up Book Pembelajaran Matematika Kelas II. Tesis , 4.

Myers, M. (2009). Qualitative Research in Business and Management. Los Angeles: Sage Publications.

Rahmawati, D. 2017. Pengembangan Media Pembelajaran Pop Up Book untuk Siswa SDLB Tunarungu Kelas IV. Skrispsi, 3.

Sadiman, A., \& dkk. (2011). Media Pendidikan. Jakarta: PT. Raja Grasindo Persada.

Sinar. (2018). Metode Active Learning: Upaya Peningkatan Keaktifan dan Hasil Belajar Siswa. Sleman: DeePublish.

Sugiyono. (2010). Metode Penelitian Pendidikan Pendekatan Kuantitatif, Kualitatif, dan $R \& D$. Bandung: Alfabeta.

Susanto, A. (2014). Pengembangan Pembelajaran IPS di Sekolah Dasar. Jakarta: Prenadamedia Group .

Susilana, R., \& Riyana, C. 2009. Media Pembelajaran. Bandung: Wacana Prima.

Suharyati, E. I. 2016. Penerapan Model Pembelajaran Kooperatif dalam Meningkatkan Kemampuan Siswa Mendeskripsikan Kondisi Fisik Wilayah dan Penduduk Indonesia. Widya Wacana 11(1): 2-11. 